\title{
Veleszületett csírahiánnyal társuló skeletalis eltérések vizsgálata
}

\author{
Mártha I. Krisztina dr. ${ }^{1}$ - Cămărășan Alina dr. ${ }^{2}$ - Pop Silvia Izabella dr. ${ }^{1}$ \\ Kerekes Máthé Bernadette dr. ${ }^{2}$ \\ ${ }^{1}$ Marosvásárhelyi Orvosi és Gyógyszerészeti Egyetem, Fogorvosi Kar, Fogszabályozás Tanszék, \\ Marosvásárhely (Târgu Mureș), Románia \\ ${ }^{2}$ Marosvásárhelyi Orvosi és Gyógyszerészeti Egyetem, Fogorvosi Kar, Fogmorfológiai és Anyagtani Tanszék, \\ Marosvásárhely (Târgu Mureș), Románia
}

Bevezetés: A veleszületett csírahiány előfordulásának gyakorisága növekvő tendenciát mutat a mindennapi gyakorlatban. Az említett rendellenesség korai kórisméje ugyanúgy, mint a társult skeletalis eltéréseké, rendkívül fontos a sikeres és stabil végleges rehabilitáció tekintetében.

Célkitüzés: 1-4 fogcsíra hiányában szenvedő páciensek kefalometriás leleteinek összehasonlítása a csírahiányban nem szenvedő kontrollcsoport mérési eredményeivel.

Anyag és módszer: A Marosvásárhelyi Orvosi és Gyógyszerészeti Egyetem Fogszabályozás Tanszékének kétéves beteganyagából kiválasztott 4l, csírahiányos páciens oldalirányú távröntgenjét értékeltük ki. Az így kapott eredményeket összehasonlítottuk a nem és életkor szerint hozzájuk rendelt kontrollcsoport értékeivel.

Eredmények: A leggyakrabban kétoldali felső metsző és kétoldali alsó kisőrlő csírahiányával találkoztunk. A mandibula növekedési irányát előre jelző NSGn-szög vizsgálatakor statisztikailag szignifikáns eltéréseket találtunk a férfi ( $\mathrm{p}=$ $0,012)$, az elülső $(\mathrm{p}=0,010)$, illetve az oldalsó csírahiányosok $(\mathrm{p}=0,024)$ csoportja és a kontrollcsoport között. A két állcsont egymáshoz viszonyított sagittalis helyzetét jelző ANB-szög vizsgálatakor statisztikai szempontból jelentős eltéréseket találtunk a nemek és a csírahiány fogíven belüli elhelyezkedése szerint elkülönített vizsgálati alcsoportok, illetve a kontrollcsoport között.

Következtetés: A csírahiányos egyének skeletalis kefalometriás értékeit összevetve a nem és életkor szerint hozzájuk rendelt kontrollcsoport értékeivel, szignifikánsan több skeletalis 3. osztályt és a két állcsont síkja által bezárt szög hipodivergenciáját találtuk a csírahiányos csoportban.

Orv Hetil. 2019; 160(6): 214-219.

Kulcsszavak: csírahiány, kefalometria, skeletalis

\section{Study of skeletal features in congenital hypodontia}

Introduction: The incidence of congenital hypodontia is increasing in daily practice. Early diagnosis of this dental disorder and the associated skeletal malocclusions is crucial for successful and stable final rehabilitation.

Aim: Comparison of cephalometric findings of patients with hypodontia of $1-4$ teeth with the measurement results of the control group without teeth agenesis.

Material and method: We evaluated the lateral X-ray of 41 patients with $1-4$ teeth agenesis selected from patients referred for orthodontic treatment to the Orthodontic Department of the University of Medicine and Pharmacy from Târgu Mureş within a two-year period. The results were compared with the values of the age and sex matched control group.

Results: Bilateral upper incisor and lower bicuspid were missing in most of the hypodontia cases. When looking at the NSGn angle predicting the growth direction of the mandible, statistically significant differences were found between the male $(\mathrm{p}=0.012)$, the front $(\mathrm{p}=0.010)$ and the hypodontia group $(\mathrm{p}=0.024)$ and the control group. Regarding the ANB angle, which shows the sagittal position of the maxilla to the mandible, statistically significant differences were found between the subgroups (women, men, anterior or posterior hypodontia) and the control group. Conclusion: Larger number of skeletal class 3 and vertical hypodivergent tendency were observed in the hypodontia group.

Keywords: hypodontia, cephalometry, skeletal 
Mártha IK, Cămărășan A, Pop SI, Kerekes Máthé B. [Study of skeletal features in congenital hypodontia]. Orv Hetil. 2019; 160(6): 214-219.

(Beérkezett: 2018. augusztus 31.; elfogadva: 2018. szeptember 26.)

A nem szindrómákhoz kötött csírahiány $1-4$ fog csírájának veleszületett hiányát jelentő fogazati rendellenesség [1]. Az európai adatok gyakoriságát 2,2\% és $10,1 \%$ között emlegetik, nagyobb számban jelenik meg a fogszabályozási kezelésre jelentkező páciensek körében, és nem sorolják a kezelendő rendellenességek sorába a bölcsességfogak hiányát. Az Erdély egyik régiójának felméréseiból származó adataink 7,39\%-os előfordulást jeleznek [2]. Egyértelmü, hogy a csírahiányok okozta rések pszichoszociális problémákat idéznek elő, ugyanazon rések pedig megzavarják a dentomaxillaris szerkezet funkcióit is. Kezelésük csapatmunka, és ennek sikeréhez a korai kórisme és a csírahiányok következményeinek megelőzése nagymértékben hozzájárul.

Bármely fogazati rendellenességhez társuló skeletalis elváltozások időben történő felismerése úgyszintén a sikeres orthodontiai kezelés titka. A koponyaalap fejlődésének és növekedésének megértése rendkívül fontos minden orthodontus számára, hisz meghatározza a teljes craniofacialis régió növekedésének és fejlődésének irányát, és az arckoponya, a fogmedernyúlványok, illetve az állcsontok helyzetét és fejlődési fokát is befolyásolja [3].

A jelen felmérés célja a csírahiánnyal társuló skeletalis rendellenességek felmérése, összehasonlítva a csírahiányos esetek kefalometriás elemzésekor mért koponyaalap-, maxilla- és mandibulahosszat, valamint az állcsontok koponyaalaphoz és egymáshoz viszonyított helyzetét mutató értékeket számbeli fogazati rendellenességben nem szenvedő alanyok értékeivel.

\section{Módszer}

A Marosvásárhelyi Orvosi és Gyógyszerészeti Egyetem Fogszabályozás Tanszékén 2016. május-2018. május periódusában szakorvosi ellátásra jelentkező 476 eset közül kiválasztottuk a csírahiányos eseteket, ezek képezték a tanulmányi csoportot. A 41 vizsgált alany életkora 10 és 20 év közötti volt, nemek szerinti eloszlásuk pedig 12 fiú és 29 lány. Vizsgálatunk alanyait a korlátozott számú (1-4) csírák hiányában szenvedő alanyok képezték, a több csíra hiányában szenvedő 4 alanyt kizártuk az egyéb társult fejlődési rendellenesség jelenléte miatt [4].

Minden vizsgált alanyhoz, a fent említett eseteinkből, egy nemben és életkorban megegyező kontrollalanyt rendeltünk, így a 12 fiúból és 29 lányból álló kontrollcsoportban az életkor szintén 10 és 20 év között mozgott.

Tanulmányunkat a Marosvásárhelyi Orvosi és Gyógyszerészeti Egyetem Tudományos Kutatás Etikai Bizottsága jóváhagyta (engedélyszám: 60/07.03.2018), a ta- nulmányban szereplő alanyok mindegyikének beleegyező nyilatkozatát megkaptuk.

A vizsgált csoportokba a következő kritériumok alapján soroltuk be az alanyokat: (1) 9 évesnél idősebb alany (a második kisőrlő kórisméje csak ebben a korban állítható fel, és a koponyaalap morfológiája is ebben az életkorban teljesedik ki); (2) nem szenved egyéb fejlődési rendellenességben (a szájpadhasadékokat is kizártuk); (3) nem szenvedett arc- vagy koponyatraumát; (4) nem részesült fogszabályozó kezelésben (a kezelés előtti képalkotó eljárásokat használtuk fel); (5) jól kiértékelhető röntgenfelvételeket birtokol; (6) a csírahiányos vizsgált csoportba sorolt alanyok mindegyike 1-4 fog csírahiányával rendelkezik (a bölcsességfogak hiányát nem soroltuk be tanulmányunkba).

A távröntgenfelvételek minden esetben ugyanazzal a röntgengéppel (Cranex D, Soredex, Finnország) készültek, kefalometriás méréseinket számítógépes program segítségével végeztük (AudaxCeph, Ljubljana, Szlovénia), módszerként pedig a zürichi Craniofacialis Növekedés Tanulmánya során kifejlesztett módszert alkalmaz-

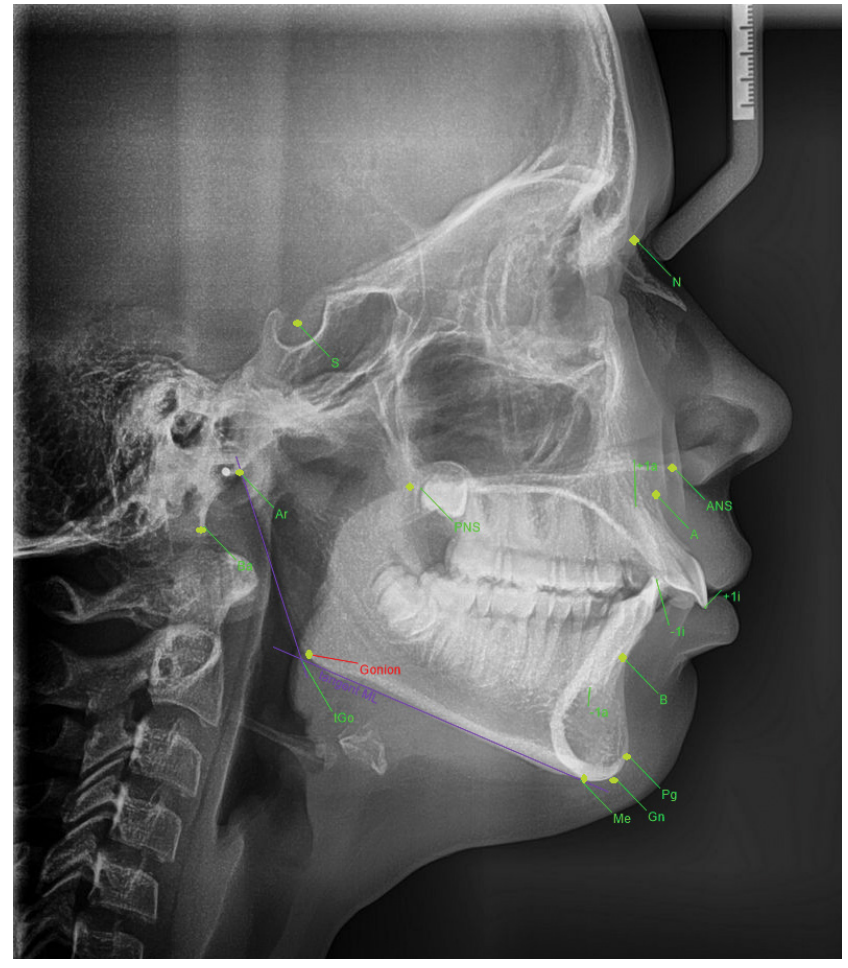

1. ábra

A méréseinkhez szükséges kefalometriás pontok azonosítása oldalirányú távröntgenfelvétel számítógépes kiértékelésekor

$\mathrm{A}=\mathrm{A}$ pont $; \mathrm{ANS}=$ spina nasalis anterior $; \mathrm{Ar}=\operatorname{articulare} ; \mathrm{B}=\mathrm{B}$ pont; $\mathrm{Ba}=$ basion; $\mathrm{Gn}=$ gnathion; $\mathrm{Me}=$ menton; $\mathrm{N}=$ nasion; $\mathrm{Pg}=$ pogonion $; \mathrm{PNS}=$ spina nasalis posterior $\mathrm{S}=$ sella 
tuk (1. ábra). A beazonosított kefalometriás pontokat, síkokat és szögeket az 1. táblázatban foglaltuk össze.

A kapott értékeket Excel-táblázatba foglaltuk, és a kiugró értékek kizárása után (Quick Outlier Calculator) SPSS 17.0 (Statistical Package for Social Sciences, Chica-

1. táblázat | A tanulmányban használt kefalometriás pontok és paraméterek meghatározása, jelölése és normálértékei (NÉ)

\begin{tabular}{|c|c|c|}
\hline \multicolumn{3}{|c|}{ Kefalometriás pontok } \\
\hline Articulare (Ar) & \multicolumn{2}{|l|}{$\begin{array}{l}\text { A temporalis csont és a processus articularis } \\
\text { mandibulae hátsó szélének metszési pontja }\end{array}$} \\
\hline Basion (Ba) & \multicolumn{2}{|l|}{$\begin{array}{l}\text { A hátsó koponyaalap leghátsó pontja, a foramen } \\
\text { magnum elülső széle }\end{array}$} \\
\hline Gnathion (Gn) & \multicolumn{2}{|l|}{$\begin{array}{l}\text { Az állcsúcs legalsó és legelülső pontja, a Pg és } \\
\text { Me közötti távolság felénél }\end{array}$} \\
\hline Gonion (Go) & \multicolumn{2}{|l|}{$\begin{array}{l}\text { A Me és Ar pontokból a mandibulatest alsó } \\
\text { széléhez, illetve a felszállóág hátulsó széléhez } \\
\text { húzott érintők által bezárt szög szögfelezője } \\
\text { által a szöglet metszési pontja }\end{array}$} \\
\hline Menton $(\mathrm{Me})$ & \multicolumn{2}{|l|}{ Az állcsúcs legalsó pontja } \\
\hline Nasion $(\mathrm{N})$ & \multicolumn{2}{|l|}{ A sutura nasofrontalis legelülső pontja } \\
\hline Pogonion $(\mathrm{Pg})$ & \multicolumn{2}{|l|}{ A mandibula symphysis legkiállóbb pontja } \\
\hline A pont $(A)$ & \multicolumn{2}{|l|}{$\begin{array}{l}\text { A felső fogmedernyúlvány legmélyebb pontja a } \\
\text { medián síkban }\end{array}$} \\
\hline B pont $(\mathrm{B})$ & \multicolumn{2}{|l|}{$\begin{array}{l}\text { Az alsó fogmedernyúlvány legmélyebb pontja a } \\
\text { medián síkban }\end{array}$} \\
\hline Sella $(S)$ & \multicolumn{2}{|l|}{ A töröknyereg középpontja } \\
\hline $\begin{array}{l}\text { Spina nasalis } \\
\text { anterior (ANS) }\end{array}$ & \multicolumn{2}{|l|}{ A spina nasalis anterior legelülső pontja } \\
\hline $\begin{array}{l}\text { Spina nasalis } \\
\text { posterior (PNS) }\end{array}$ & \multicolumn{2}{|l|}{$\begin{array}{l}\text { A fossa pterygopalatina csúcsának vetülete az } \\
\text { orrüreg alapjára }\end{array}$} \\
\hline \multicolumn{3}{|l|}{ Távolságok (mm) } \\
\hline $\mathrm{S}-\mathrm{N}$ & \multicolumn{2}{|l|}{ Az elülső koponyaalap hossza } \\
\hline ANS-PNS & \multicolumn{2}{|l|}{ A maxilla hossza } \\
\hline Gn-Go & \multicolumn{2}{|l|}{ A mandibula testének hossza } \\
\hline Szögek $\left(^{\circ}\right)$ & & NÉ \\
\hline ANB & $\begin{array}{l}\text { A két állcsont egymáshoz viszonyított } \\
\text { helyzete sagittalis síkban, a NA és NB } \\
\text { síkok alkotják }\end{array}$ & 3 \\
\hline SNA & $\begin{array}{l}\text { A maxilla sagittalis helyzete a koponya- } \\
\text { alaphoz viszonyítva, a SN és NA síkok } \\
\text { alkotják }\end{array}$ & 82 \\
\hline SNB & $\begin{array}{l}\text { A mandibula sagittalis helyzete a } \\
\text { koponyaalaphoz viszonyítva, a SN és NB } \\
\text { síkok alkotják }\end{array}$ & 79 \\
\hline $\mathrm{SN} / \mathrm{NL}$ & $\begin{array}{l}\text { A maxilla síkjának helyzete a koponyaalap- } \\
\text { hoz viszonyítva }\end{array}$ & 7 \\
\hline $\mathrm{ML} / \mathrm{NL}$ & $\begin{array}{l}\text { A maxilla és a mandibula alapsíkja által } \\
\text { bezárt szög }\end{array}$ & 28 \\
\hline NSGn & $\begin{array}{l}\text { Az állcsúcs helyzete a koponyaalaphoz } \\
\text { viszonyítva }\end{array}$ & 66 \\
\hline $\mathrm{SN}-\mathrm{Ba}$ & $\begin{array}{l}\text { Az elülső és a hátulsó koponyaalap síkja } \\
\text { által bezárt szög }\end{array}$ & 129 \\
\hline $\mathrm{Pg} / \mathrm{NB}$ & $\begin{array}{l}\text { Az állcsúcs helyzete a NB síkhoz } \\
\text { viszonyítva }\end{array}$ & -4 \\
\hline
\end{tabular}

go, IL, Amerikai Egyesült Államok) program segítségével a következő statisztikai elemzéseket végeztük el (szignifikanciaszint $\mathrm{p}<0,05$ ):

- az értékek eloszlásának vizsgálata Shapiro-Wilk-teszt segítségével;

- leíró statisztika az átlagértékek és standard deviációk kiszámítására;

- független t-próbák elvégzése a kontroll- és esetcsoportok között, minden paraméter esetében;

- khí-négyzet-próbák annak vizsgálatára, hogy van-e különbség bizonyos skeletalis osztályok előfordulásában a kontroll- és esetcsoportok között.

\section{Eredmények}

A csírahiányos vizsgálati csoportban tapasztalt elülső (metszőfogak) és/vagy oldalsó fogak (kisőrlők) hiányát, illetve az egy- vagy kétoldali csírahiányok helyzetét a 2. táblázatban foglaltuk össze.

A kapott értékeket táblázatba foglaltuk, kiugró értékeket nem találtunk. Öt távröntgen esetében a méréseket másodszor is elvégeztük, a méréseken belül ejtett hiba vizsgálatakor a kapott korrelációs együttható értéke minden mérésre vonatkozóan 0,85 fölött volt, ami kiválónak számít.

A 3. táblázatban az életkor, valamint a mért paraméterek átlagértéke és standard deviációja látható, a vizsgált csoportokra és ezen belül nemekre lebontva.

Az átlagértékek és standard deviációk számítását az alanyok nemétől függetlenül, a két teljes vizsgálati csoportra is elvégeztük, és a 4. táblázatba foglaltuk.

A továbbiakban minden vizsgált paraméter esetén független t-próbát végeztünk, a csírahiányos és a kontrollcsoport értékeit hasonlítva össze. Eredményeinket a 5. táblázatban foglaltuk össze.

A khí-négyzet-próbák segítségével arra mutattunk rá, hogy a két vizsgált csoport között milyen különbségek vannak az egyes skeletalis osztályok előfordulását tekintve. A skeletalis 1 . osztály $\left(2^{\circ}<\mathrm{ANB}<4^{\circ}\right)$ esetében nem találtunk különbséget $(p=0,618)$, szignifikáns eltérést találtunk azonban a skeletalis 2 . osztály $\left(\mathrm{ANB}<2^{\circ}\right)$ és 3 . osztály $\left(\mathrm{ANB}>4^{\circ}\right)$ esetében, ahol a szignifikancia értéke 0,027 , illetve 0,002 volt.

\section{Megbeszélés}

A Marosvásárhelyi Orvosi és Gyógyszerészeti Egyetem Fogszabályozás Tanszékén a fentebb említett periódusban fogszabályozásra jelentkező 476 páciens között 41 esetben volt kórismézhető a csírahiány, ami 8,61\%-os előfordulást jelent. Ez a frekvencia megegyezik más, hasonló jellegü felmérést végző, régiónkbeli tanulmányok eredményével [5-9].

A nemek szerinti eloszlást véve alapul, betegeink 70,73\%-a nő, más szóval a tanulmányozott fogazati rendellenesség gyakoribb lányoknál, mint ezt a szakirodalom sok esetben nyugtázza $[10,11]$. 
2. táblázat |A vizsgált csírahiányoknak a fogívek régiója szerinti eloszlása

\begin{tabular}{|c|c|c|c|c|c|c|c|c|c|c|}
\hline \multicolumn{5}{|c|}{ Felső csírahiány } & \multicolumn{5}{|c|}{ Alsó csírahiány } & \multirow{3}{*}{$\begin{array}{l}\text { Alsó + felső } \\
\text { csírahiány }\end{array}$} \\
\hline \multicolumn{3}{|c|}{ Egyoldali } & \multicolumn{2}{|c|}{ Kétoldali } & \multicolumn{3}{|c|}{ Egyoldali } & \multicolumn{2}{|c|}{ Kétoldali } & \\
\hline \multicolumn{2}{|c|}{ Metsző } & Kisőrlő & Metsző & Kisőrlő & Metsző & \multicolumn{2}{|c|}{ Kisőrlő } & Metsző & Kisőrlő & \\
\hline \multicolumn{2}{|l|}{6} & 1 & 9 & 2 & 1 & \multicolumn{2}{|l|}{7} & 1 & 8 & 6 \\
\hline \multicolumn{2}{|c|}{$14,63 \%$} & $2,43 \%$ & $21,95 \%$ & $4,87 \%$ & $2,43 \%$ & \multicolumn{2}{|c|}{$17,07 \%$} & $2,43 \%$ & $19,51 \%$ & $14,63 \%$ \\
\hline 1.2 . & 2.2 . & & & & & 3.5 . & 4.5 . & & & \\
\hline 5 & 1 & & & & & 2 & 5 & & & \\
\hline
\end{tabular}

3. táblázat |A mért paraméterek átlagértéke (ÁÉ) és standard deviációja (SD) (n: esetszám)

\begin{tabular}{|c|c|c|c|c|c|c|c|c|c|c|}
\hline \multirow[t]{3}{*}{ Mért paraméterek } & \multicolumn{5}{|c|}{ Nö } & \multicolumn{5}{|c|}{ Férfi } \\
\hline & \multirow[b]{2}{*}{$\mathrm{n}$} & \multicolumn{2}{|c|}{ Kontroll } & \multicolumn{2}{|c|}{ Csírahiány } & \multirow[b]{2}{*}{$\mathrm{n}$} & \multicolumn{2}{|c|}{ Kontroll } & \multicolumn{2}{|c|}{ Csírahiány } \\
\hline & & ÁÉ & SD & ÁÉ & SD & & ÁÉ & SD & ÁÉ & SD \\
\hline Életkor & 29 & 13,97 & 2,822 & 14,172 & 3,596 & 12 & 12,50 & 1,732 & 14,333 & 4,923 \\
\hline $\mathrm{SN} / \mathrm{NL}\left({ }^{\circ}\right)$ & 29 & 6,534 & 3,765 & 7,508 & 3,689 & 12 & 6,785 & 2,494 & 4,709 & 3,760 \\
\hline $\mathrm{ML} / \mathrm{NL}\left({ }^{\circ}\right)$ & 29 & 27,847 & 6,114 & 26,879 & 5,383 & 12 & 27,376 & 6,110 & 25,791 & 3,848 \\
\hline NSGn $\left(^{\circ}\right)$ & 29 & 66,995 & 3,363 & 65,697 & 3,635 & 12 & 67,672 & 3,521 & 63,403 & 4,162 \\
\hline $\operatorname{SNA}\left({ }^{\circ}\right)$ & 29 & 83,475 & 4,060 & 81,650 & 3,587 & 12 & 81,135 & 3,586 & 81,487 & 4,170 \\
\hline $\mathrm{SNB}\left({ }^{\circ}\right)$ & 29 & 78,676 & 3,791 & 78,931 & 3,344 & 12 & 76,167 & 2,653 & 79,575 & 4,987 \\
\hline $\operatorname{ANB}\left({ }^{\circ}\right)$ & 29 & 4,801 & 2,395 & 2,721 & 2,482 & 12 & 4,97 & 2,388 & 1,910 & 2,727 \\
\hline Go $\left(^{\circ}\right)$ & 29 & 131,644 & 6,616 & 2,034 & 0,778 & 12 & 130,197 & 6,723 & 2,416 & 0,792 \\
\hline $\mathrm{SN}-\mathrm{Ba}\left({ }^{\circ}\right)$ & 29 & 127,655 & 7,367 & 131,417 & 7,116 & 12 & 129,27 & 4,113 & 129,585 & 5,195 \\
\hline $\mathrm{S}-\mathrm{N}(\mathrm{mm})$ & 29 & 66,705 & 3,037 & 127,687 & 4,745 & 12 & 69,140 & 3,959 & 129,355 & 5,991 \\
\hline ANS-PNS (mm) & 29 & 49,933 & 3,433 & 65,240 & 3,353 & 12 & 51,515 & 5,050 & 69,421 & 4,611 \\
\hline Gn-Go $(\mathrm{mm})$ & 29 & 66,083 & 4,811 & 48,823 & 3,902 & 12 & 68,786 & 6,315 & 50,638 & 5,057 \\
\hline
\end{tabular}

4. táblázat |A két vizsgált csoportban mért paraméterek átlagértékei (ÁÉ) és standard deviációi (SD) (n: esetszám)

\begin{tabular}{|c|c|c|c|c|c|}
\hline & \multirow[t]{2}{*}{$\mathrm{n}$} & \multicolumn{2}{|l|}{ ÁÉ } & \multicolumn{2}{|l|}{ SD } \\
\hline & & Kontroll & Csírahiány & Kontroll & Csírahiány \\
\hline Életkor & 41 & 13,54 & 14,22 & 2,618 & 3,966 \\
\hline $\mathrm{SN} / \mathrm{NL}\left({ }^{\circ}\right)$ & 41 & 6,6076 & 6,6893 & 3,41342 & 3,88310 \\
\hline $\mathrm{ML} / \mathrm{NL}\left({ }^{\circ}\right)$ & 41 & 27,7095 & 26,5607 & 6,04077 & 4,96125 \\
\hline NSGn $\left(^{\circ}\right)$ & 41 & 67,1939 & 65,0259 & 3,38014 & 3,89008 \\
\hline SNA $\left(^{\circ}\right)$ & 41 & 82,7907 & 81,6024 & 4,03003 & 3,71445 \\
\hline $\operatorname{SNB}\left({ }^{\circ}\right)$ & 41 & 77,9420 & 79,1198 & 3,65206 & 3,84167 \\
\hline $\operatorname{ANB}\left({ }^{\circ}\right)$ & 41 & 4,8507 & 2,4841 & 2,36489 & 2,54959 \\
\hline Go $\left(^{\circ}\right)$ & 41 & 131,2210 & 130,8812 & 6,59721 & 6,60186 \\
\hline $\mathrm{SN}-\mathrm{Ba}\left({ }^{\circ}\right)$ & 41 & 128,1280 & 128,1756 & 6,57254 & 5,12105 \\
\hline $\mathrm{S}-\mathrm{N}(\mathrm{mm})$ & 41 & 67,4183 & 66,4641 & 3,46824 & 4,17530 \\
\hline $\begin{array}{l}\text { ANS-PNS } \\
(\mathrm{mm})\end{array}$ & 41 & 50,3966 & 49,3544 & 3,97487 & 4,28888 \\
\hline $\begin{array}{l}\text { Gn-Go } \\
(\mathrm{mm})\end{array}$ & 41 & 66,8749 & 69,1356 & 5,35967 & 6,15325 \\
\hline
\end{tabular}

5. táblázat

A kontroll- és esetcsoportok között elvégzett független t-pró bák eredményei (p-értékek), minden paraméter esetében $(\mathrm{pl}$ férfiak közötti különbség csírahiány-kontroll, p2: nők közötti különbség csírahiány-kontroll, p3: elülső hiányosok és kontrollcsoport közötti különbség, p4: oldalsó hiányosok és kontrollcsoport közötti különbség) ( * szignifikáns $p<0,05,{ }^{* *}$ kifejezetten szignifikáns $p<0,01$ )

\begin{tabular}{lllll}
\hline & $\mathrm{p} 1$ & $\mathrm{p} 2$ & $\mathrm{p} 3$ & $\mathrm{p} 4$ \\
\hline SN/NL & 0,125 & 0,323 & 0,239 & 0,421 \\
\hline ML/NL & 0,455 & 0,524 & 0,833 & 0,162 \\
\hline NSGn & $0,012^{*}$ & 0,163 & $0,010^{*}$ & $0,024^{*}$ \\
\hline SNA & 0,826 & 0,074 & 0,259 & 0,407 \\
\hline SNB & $0,048^{*}$ & 0,787 & 0,088 & 0,464 \\
\hline ANB & $0,007^{*}$ & $0,001^{* *}$ & $0,00006^{* *}$ & $0,009^{*}$ \\
\hline Go & 0,805 & 0,900 & 0,630 & 0,473 \\
\hline SN-Ba & 0,968 & 0,984 & 0,392 & 0,665 \\
\hline S-N & 0,873 & 0,086 & 0,739 & 0,228 \\
\hline ANS-PNS & 0,674 & 0,254 & 0,663 & 0,174 \\
\hline Gn-Go & 0,087 & 0,318 & 0,062 & 0,267 \\
\hline
\end{tabular}


A kiválasztott csírahiányos esetek képezte csoporton belül 6 esetben találtunk mindkét fogívre lokalizálódó csírahiányt, míg a külön alsó vagy felső fogív csíráinak hiánya jellemezte esetek a vizsgált csoportunkon belül azonos számban voltak fellelhetők. Összességében gyakoribb volt az oldalsó fogak hiánya $(55,26 \%)$, mint a metszőké $[12,13]$.

A 41 vizsgált eset között a leggyakrabban kétoldali felső metsző és kétoldali alsó kisőrlő csírahiányával találkoztunk, gyakorisági sorrendben a felső jobb kismetsző, az alsó kisőrlők és a felső bal kismetsző hiányzott. Az alsó metsző hiányával két esetben találkoztunk. Statisztikai adataink az érintett fogív és csírák tekintetében megegyeznek a szakirodalomban fellelhetőkkel [14, 15].

Számítógépes kefalometriás kiértékeléshez a zürichi Craniofacialis Növekedés Tanulmánya során meghatározott pontokat, paramétereket és átlagértékeket használtuk fel, azon egyszerü oknál fogva, hogy az említett tanulmány európai alanyok értékeit veszi figyelembe, és azok minden bizonnyal közelebb állnak az általunk tanulmányozott alanyok értékeihez [16].

A kapott eredményeket elemezve, nem találtunk szignifikáns eltéréseket a maxilla koponyaalaphoz vagy mandibulához viszonyított vertikális irányú helyzetét jellemző kefalometriás értékek között, sem a nemek, sem a csírahiány fogív menti elhelyezkedése szerinti felosztásban [17].

A mandibula vertikális irányú növekedését előrevetítő NSGn-szög - az állcsúcs legalsó és legelülső pontjának (Gn) az elülső koponyaalaphoz viszonyított helyzetét leíró szög - kapott értékeit elemezve, szignifikáns eltéréseket tapasztaltunk a férfi csírahiányos esetek, valamint az elülső és oldalsó csírahiányos esetek kontrollcsoporttal történő összehasonlításakor. Az említett három csoportban normálérték alatti átlagértéket kaptunk, ami azt jelzi, hogy csírahiányos esetekben az elülső arcmagasság csökkenő tendenciát mutat, ami hipodivergens arctípus kialakulását jelenti [18].

A két állcsont koponyaalaphoz viszonyított sagittalis helyzetét leíró SNA- és SNB-szögek értékeit összehasonlítva - nemek vagy a csírahiány lokalizációja szerinti felosztásban - szignifikáns eltérést csak a csírahiányos férfiak és a kontrollcsoport között találtunk. Ennek ellenére a két állcsont egymáshoz viszonyított helyzetét leíró, anteroposterior síkban mért ANB-szög minden összehasonlításban szignifikáns eltérést mutatott. Az elülső csírahiányos esetek kefalometriás értékeit összehasonlítva a kontrollok értékeivel, ez az eltérés jelentősen szignifikáns volt $(\mathrm{p}=0,00006)$. Ez az észrevételünk megcáfolja azon kijelentéseket, miszerint a skeletalis 3. osztály gyakrabban alakul ki oldalsó fogak (kisőrlők) csírahiánya esetén [19-21], vagy éppen alátámasztja azokat a tanulmányokat, amelyek ezt a típusú skeletalis rendellenességet nem a hiányzó csírák típusával, hanem azok számával hozza összefüggésbe [18, 22].

A maxilla és a mandibula sagittalis hosszát mérő paraméterek átlagértékeit összehasonlítva látható, hogy csí- rahiányos eseteknél a maxilla alapsíkja rövidebb, így a csírahiányos esetek csoportjában nagyobb számban megjelenő 3. osztályú rendellenességet ezzel is magyarázhatjuk $[23,24]$.

Az elülső és hátulsó koponyaalap síkja által bezárt szög és az állkapocs szögének átlagértéke a két vizsgált csoportban majdnem azonos értéket mutat, az elülső koponyaalap hosszát és a felső állcsont hosszát mutató átlagértékek közötti különbség elenyésző. Szintén átlagértéket tanulmányozva, a mandibula testének hosszát mérve nagyobb eltérés tapasztalható anélkül, hogy az előbb említett mérések közötti különbség statisztikailag szignifikáns lenne [25]. Annak ellenére, hogy a mindennapi gyakorlatban növekvő tendenciát mutat a bölcsességfogak csírahiánya, mi ezeket az eseteket tanulmányunkból kizártuk. Ahhoz, hogy a harmadik nagyőrlő csírahiánya teljes bizonyossággal kórismézhető legyen, a csonton belüli mineralizálódása olyan szintet kell, hogy elérjen, hogy röntgenárnyék alapján ez lehetséges legyen. Későn fejlődő fogról van szó, eseteink egy része pedig 12 év alatti, amikor ez a kórisme kétséges [26, 27].

Tanulmányunkban kétdimenziós képalkotó eljárásokat értékeltünk ki, a teljes orthodontiai kórisméhez szükséges panoráma- és lateralis röntgenfelvételeken kerestük a csírahiány és a skeletalis rendellenességek közötti öszszefüggést. A háromdimenziós imagisztikai eljárások pontosabb információkat szolgáltatnak ezekről, a vizsgált egyének életkora azonban leszúkíti ezek indikációs lehetőségét [28].

\section{Következtetések}

Tanszékünk kétéves beteganyagát feldolgozva, a fogszabályozó kezelésre jelentkező esetek 8,61\%-a rendelkezik 1-4 fogat érintő csírahiánnyal. A csírahiány - észrevételeink szerint - gyakrabban jelentkezik nőknél, eseteink kétharmadában találtuk. Gyakoribb volt a kétoldali csírahiány és az oldalsó fogak csírahiánya. A leggyakrabban a felső jobb kismetsző, az alsó kisőrlők és a felső bal kismetsző hiányával szembesültünk. A csírahiányos egyének skeletalis kefalometriás értékeit összevetve a nem és életkor szerint hozzájuk rendelt kontrollcsoport értékeivel, szignifikánsan több skeletalis 3. osztályt és a két állcsont síkja által bezárt szög hipodivergenciáját találtuk a csírahiányos csoportban.

Anyagi támogatás: A jelen tanulmány elkészültét a Marosvásárhelyi Orvosi és Gyógyszerészeti Egyetem 15609/14/29.12.2017. számú belső pályázata támogatta.

Szerzôi munkamegosztás: M. I. K.: A tanulmányba bevont esetek szelektálása, az anyag és módszer - távröntgenek és mérések kiértékelése, a közlemény végleges szerkesztése. C. A.: A kefalometriás mérések elvégzése az AudaxCeph program segítségével, az adatok összesítése, 
a szakirodalom tanulmányozása. P. S. I.: Az AudaxCeph program felhasználása, az eredmények végső kiértékelése. K. M. B.: Az adatok statisztikai feldolgozása és kiértékelése, a közlemény végleges szerkesztése. A cikk végleges változatát valamennyi szerző elolvasta és jóváhagyta.

Érdekeltségek: A szerzőknek nincsenek érdekeltségeik.

\section{Irodalom}

[1] Sólya K, Dézsi C, Vanya M, et al. Clinical aspects of congenital maxillofacial deformities. [A veleszületett maxillofacialis deformitások klinikai aspektusai.] Orv Hetil. 2015; 156: 1483-1490. [Hungarian]

[2] Kerekes-Máthé B, Mártha K, Székely M. Prevalence and characteristics of tooth agenesis in permanent dentition of subjects from Tîrgu Mureș. Acta Med Marisiensis 2013; 59: 187-190.

[3] Brodie AG Jr. The behavior of the cranial base and its components as revealed by serial cephalometric roentgenograms. Angle Orthod. 1955; 25 : 148-160.

[4] Wang HW, Wang F, Huang W, et al. Morphometric analysis of maxillofacial bone in 48 patients with ectodermal dysplasia. Shanghai Kou Qiang Yi Xue 2017; 26: 193-197.

[5] Kerekes-Máthé B, Brook AH, Mártha K, et al. Mild hypodontia is associated with smaller tooth dimensions and cusp numbers than in controls. Arch Oral Biol. 2015; 60: 1442-1449.

[6] Zegan G, Dascalu CG, Mavru RB. Hypodontia of permanent teeth in a group of young patients from the north-eastern region of Romania. Int J Med Dent. 2013; 3: 155-161.

[7] Corega C, Şerbănescu A, Corega M, et al. The prevalence of hypodontia in children with cleft and nonrelated controls. Romanian J Oral Rehabil. 2010; 2: 21-25.

[8] Rakhshan V. Congenitally missing teeth (hypodontia): a review of the literature concerning the etiology, prevalence, risk factors, patterns and treatment. Dent Res J. 2015; 12: 1-13.

[9] Fernandez CC, Pereira CV, Luiz RR, et al. Dental anomalies in different growth and skeletal malocclusion patterns. Angle Orthod. 2018; 88: 195-201.

[10] Varela M, Arrieta P, Ventureira C. Non-syndromic concomitant hypodontia and supernumerary teeth in an orthodontic population. Eur J Orthod. 2009; 31: 632-637.

[11] Rakhshan V, Rakhshan A. Systematic review and meta-analysis of congenitally missing permanent dentition: sex dimorphism, occurrence patterns, associated factors and biasing factors. Int Orthod. 2016; 14: 273-294.

[12] Rózsa N, Nagy K, Vajó Z, et al. Prevalence and distribution of permanent canine agenesis in dental paediatric and orthodontic patients in Hungary. Eur J Orthod. 2009; 31: 374-379.

[13] Vucic S, Dhamo B, Kuijpers MA, et al. Craniofacial characteristics of children with mild hypodontia. Am J Orthod Dentofacial Orthop. 2016; 150: 611-619.
[14] Al-Ani AH, Antoun JS, Thomson WM, et al. Hypodontia: an update on its etiology, classification, and clinical management. Biomed Res Int. 2017; 2017: 9378325

[15] Barber S, Bekker HL, Meads D, et al. Identification and appraisal of outcome measures used to evaluate hypodontia care: a systematic review. Am J Orthod Dentofacial Orthop. 2018; 153: 184-194.el8.

[16] Mislik B, Hänggi MP, Signorelli L, et al. Pharyngeal airway dimensions: a cephalometric, growth-study-based analysis of physiological variations in children aged 6-17. Eur J Orthod. 2013; 36: 331-339

[17] Kreczi A, Proff P, Reicheneder C, et al. Effects of hypodontia on craniofacial structures and mandibular growth pattern. Head Face Med. 2011; 7: 23.

[18] Chung LK, Hobson RS, Nunn HJ, et al. An analysis of the skeletal relationships in a group of young people with hypodontia. J Orthod. 2000; 27: 315-318.

[19] Bassiouny DS, Afify AR, Baeshen HA, et al. Prevalence of maxillary lateral incisor agenesis and associated skeletal characteristics in an orthodontic patient population. Acta Odontol Scand. 2016; 74: 456-459.

[20] Chan DW, Samman N, McMillan AS. Craniofacial profile in Southern Chinese with hypodontia. Eur J Orthod. 2009; 31: 300-305.

[21] Buyuk SK, Ozkan S, Benkli YA, et al. Evaluation of the skeletal and dental effects in orthodontic patients with maxillary lateral incisor agenesis. J Esthetic Restor Dent. 2017; 29: 284-290.

[22] Acharya PN, Jones SP, Moles D, et al. A cephalometric study to investigate the skeletal relationships in patients with increasing severity of hypodontia. Angle Orthod. 2010; 80: 511-518.

[23] Øgaard B, Krogstad O. Craniofacial structure and soft tissue profile in patients with severe hypodontia. Am J Orthod Dentofacial Orthop. 1995; 108: 472-477.

[24] Fekonja A. Hypodontia in orthodontically treated children. Eur J Orthod. 2005; 27: 457-460.

[25] Hirukawa K, Iwata R, Kurosawa M, et al. Statistical investigation about the prevalence of congenitally missing permanent teeth. Orthod Waves 1999; 58: 49-56.

[26] Huang Y, Yan Y, Cao J, et al. Observations on association between third molar agenesis and craniofacial morphology. J Orofac Orthop. 2017; 78: 504-510.

[27] Fernandez CC, Pereira CV, Luiz RR, et al. Third molar agenesis as a potential marker for craniofacial deformities. Arch Oral Biol. 2018; 88: 19-23.

[28] Kapila SD, Nervina JM. CBCT in orthodontics: assessment of treatment outcomes and indications for its use. Dentomaxillofac Radiol. 2014; 44: 20140282.

(Mártha I. Krisztina dr., Marosvásárbely, Erdő (Pădurii) u. 30., 540082, Románia e-mail: marthakriszti@yahoo.com)

\section{"Sic fata volunt." (A sors akarta így.)}

